\title{
New APSA Executive Director Announced
}

APSA announces Steven Rathgeb Smith as the incoming executive director of the association. Michael Brintnall, who has served as executive director since 2003, is retiring. After an extensive yearlong search, the APSA Council unanimously endorsed the recommendation to select Smith as the new executive director.

Smith brings to his role broad interests and commitment to every part of political science and deep experience with professional associations and nonprofit management. "Steve has a line of experience that is perfect for this job," said APSA president Jane Mansbridge in her video announcement of his appointment posted online in April 2013.

\section{BACKGROUND}

Smith was recently the Louis A. Bantle Chair in Public Administration at the Maxwell School of Syracuse University and is renowned for his research and publications on nonprofit organizations, public management, and social policy. He was a long-time faculty member of the Evans School of Public Affairs at the University of Washington where he was the Nancy Bell Evans Professor of Public Affairs and the founding director of the Nancy Bell Evans Center on Nonprofits and Philanthropy at the Evans School. He was also the associate dean of the Evans School and founded and chaired the first diversity committee at the school. He has also taught at American University, Duke University, Georgetown University, and Washington University at St. Louis. Smith served as president of the Association for Research on Nonprofit Organizations and Voluntary Action from 2006 to 2008.

"As president for two important years of the professional association of scholars in the nonprofit field," said Mansbridge, "Steve led a strategic planning initiative that, by consensus, completely overhauled the bylaws and instituted new priorities for the organization, including teaching and curriculum issues and an increased attention to diversity."

He served as editor of the Nonprofit and Voluntary Sector Quarterly from 1996 to 2004 , where he negotiated new publisher contracts and raised the visibility and prominence of the journal. "Over his seven-year editorship the number of subscribers and the impact factor of the

\section{Steven Rathgeb Smith}

I am very excited and honored by this opportunity to lead the association. I have been a member of the APSA since I was in graduate school so I know that the APSA is a wide ranging and diverse association of scholars and practitioners who bring multiple perspectives to the study of politics. Through both teaching and research APSA members shape the understanding of politics, civic engagement, and social capital building of everyone in this country. We know that citizens' understandings of their civic responsibilities can be profoundly influenced by political science through classroom instruction and timely research.

Political science can also help us understand the relationship between politics and the economy and the evolving relationship among different nation states. An engaged political science profession can be on the forefront of important worldwide developments such as the movement for greater transparency in government, more citizen participation through local community organizations, and new forms of governance and accountability. Popular movements in many countries are leading to greater democracy but also to fundamental governmental restructuring, often at great cost. Political science is essential in helping us understand these important developments.

Yet the APSA, like other academic associations, is in a period of transition due to trends in academic publishing, higher education, and public policy. Thus, the position of APSA Executive Director holds both challenge and opportunity. I am very much looking forward to working with the APSA membership to support your professional goals and to represent the interest of political scientists in the public arena. Given its extensive and diverse

membership, APSA and its members are in a position to play a leading role in shaping the future of higher education and public policy.

I have been a member of the APSA for over 30 years and see this executive director position as the culmination of my teaching, research, and professional experience with APSA and other academic associations. Throughout my academic career I have been especially interested in civic engagement, the role of nonprofit organizations in the policy process, and the governance of public policy in the United States and abroad. My work with academic associations based in the United States and Europe, and as an editor of an association journal, has made me very aware of the challenges facing professional associations today.

I would like to thank current APSA president Jenny Mansbridge, presidentelect John Aldrich, and the search committee for the courteous and careful search process. I look forward to working with you, the APSA membership, along with your council, Jenny, John, and the APSA staff as we seek to promote high-quality research and teaching in the discipline as well as more engagement in the policy process by political scientists, educators, and the citizenry. I look forward to meeting some of you at the APSA Annual Meeting in August 2013 and hope to meet many of you in the years to come. Thank for you offering me this opportunity. 


\section{Coming in the NEXT ISSUE}

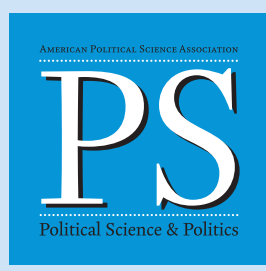

A preview of some of the articles in the October 2013 issue:

\section{SYMPOSIUM}

After the Arab Spring: Prospects for (In)security

John Gledhill, guest editor

\section{FEATURES}

Socially Mediated Internet Surveys (SMIS): Recruiting Participants for Online Experiments

Erin Cassese

Katrina Seven Years On: Politics of Race and Recovery

Christine L. Day

Support at Any Distance? The Role of Location and Prejudice in Public Opposition to the "Ground Zero Mosque"

Brian F. Schaffner

Misconceptions and Realities of the 2011 Tunisian Election

Nawel Amrouche

THE PROFESSION

Book Citations Count

David J. Samuels

\section{THE TEACHER}

The Short-Term 'Bridge Model' Study Abroad Program: Peacebuilding in Latin America

Jeffrey Pugh

The Settlement Game: A Simulation Teaching Institutions Theories of Public Law

Dave Bridge

Should "I" Be Avoided or Embraced?

Exploring Divergence between

Political Scientist and Student

Writing Norms

Edward L. Lascher

\section{ASSOCIATION NEWS}

APSA 2013 Annual Meeting Recap journal grew substantially," emphasized Mansbridge. He currently serves on a number of editorial boards and has been very involved in several academic associations. His extensive publishing portfolio includes Government and Regulation in the Third Sector (2010); Old Assumptions, New Realities: Economic Security for 21st Century Working Families (2010); and Nonprofits for Hire: The Welfare State in the Age of Contracting (1993).

Mansbridge concluded, "Steve really knows the world of professional associations and journals, and he is deeply aware of the challenges that all professional associations face."

Smith holds a $\mathrm{PhD}$ in political science from MIT. His term begins in August 2013.

\section{THE SEARCH COMMITTEE AND PROCESS}

In 2011 APSA president G. Bingham Powell, Jr., and then president-elect Jane Mansbridge formed a search committee chaired by Margaret Levi and vice- chaired by Kay Scholzman to search for a new executive director. The committee included Margaret Levi, Search Committee Chair, University of Washington; Kay L. Schlozman, Search Committee Vice-Chair, Boston College; Michelle D. Deardorff, Jackson State University; Henry Farrell, George Washington University; Stathis N. Kalyvas, Yale University; Walter R. Mebane, Jr. University of Michigan; Julie Novkov, University at Albany, SUNY; and Charles A. (Tony) Smith, University of California, Irvine.

In a video, posted at on the APSA website, Mansbridge details Smith's strengths as the next executive director and describes the process leading to his selection. Also Smith introduces himself and his understanding of the challenges and opportunities facing the association. Other details are available at http://www .apsanet.org/executivedirectorannounce ment/. The announcement was also sent to all APSA members and included in the April all-member newsletter (e-mail). 